\title{
Assuring Not-For-Profit Hospital Competitiveness Through Proper Accounting For The True Cost Of Capital
}

Rakesh Duggal, Southeastern Louisiana University, USA

Michael Craig Budden, Southeastern Louisiana University, USA

\begin{abstract}
The topic of cost of capital is very important, especially for not-for-profit (NFP) organizations. Since profit maximization or stockholder wealth maximization cannot be their objective, NFP firms must be all the more aware of their costs, including the cost of capital, to sustain and grow the quality and quantity of their services to their consumers. Yet, research into this topic has been lagging. This paper adapts and enhances an existing methodology and illustrates how a nonprofit hospital's cost of capital can be estimated.
\end{abstract}

Keywords: Cost of Capital, Non-profit, health care, hospital, not-for-profit

\section{INTRODUCTION}

e $\mathrm{n}$ the U.S., healthcare costs are increasing faster than the GDP growth rate. NFP hospitals, which outnumber for-profit community hospitals, must bear these rising costs and a study reports that many are on the brink of insolvency ${ }^{1}$. Holstein and Litzinger (2008) discussed how European and Canadian health care systems began to focus on cost containment after moving to make health care services available universally. This contrasts with the US, where costs containment efforts typically preceded efforts to expand those covered. Regardless, cost containment efforts must take into account the true cost of the service or distortions and planning difficulties will occur. Indeed, cost of capital is one of those costs that must be managed and managed efficiently.

It is imperative that all organizations be aware of their cost of capital (also known as the weighted average cost of capital or WACC), which is defined as the average rate of return required by the suppliers of capital (lenders and shareholders). This is also the rate that an organization must require from all its investments in order to maintain the organizational value. An organization that makes investment decisions ignoring its cost of capital is likely to face financial hardships in its future. The method for estimating a for-profit firm's cost of capital is wellestablished and displayed in Table $1^{2}$.

However, not much attention has been devoted to estimating a not-for-profit's (NFP) cost of capital, so much so that even leading textbooks on healthcare financial management sidestep this topic ${ }^{3}$. This is mainly due to difficulties in estimating the cost of net assets. What rate of return should a community (or trust) expect for its stake (i.e. net assets) in the hospital? ${ }^{4}$

\footnotetext{
1 "Many Hospitals on Brink of Insolvency, Study Finds," Wall Street Journal, April 30, 2008, p. B7A.

${ }^{2}$ See Brealey, Meyers, and Allen (2006) for theory of cost of capital and weighted average cost of capital.

${ }^{3}$ See Financial Management of Health Care Organizations by Zelman, McCue, Millikan, and Glick (Blackwell Publishing) and The Financial Management of Hospitals and Healthcare Organizations by Nowicki (Health Administration Press).

${ }^{4}$ Government (state or local) owned healthcare facilities are excluded from our discussion because a government's decision making process is different from that of a free market entity. This paper deals with charity hospitals, with or without religious affiliations, which primarily depend on donations to provide health care.
} 


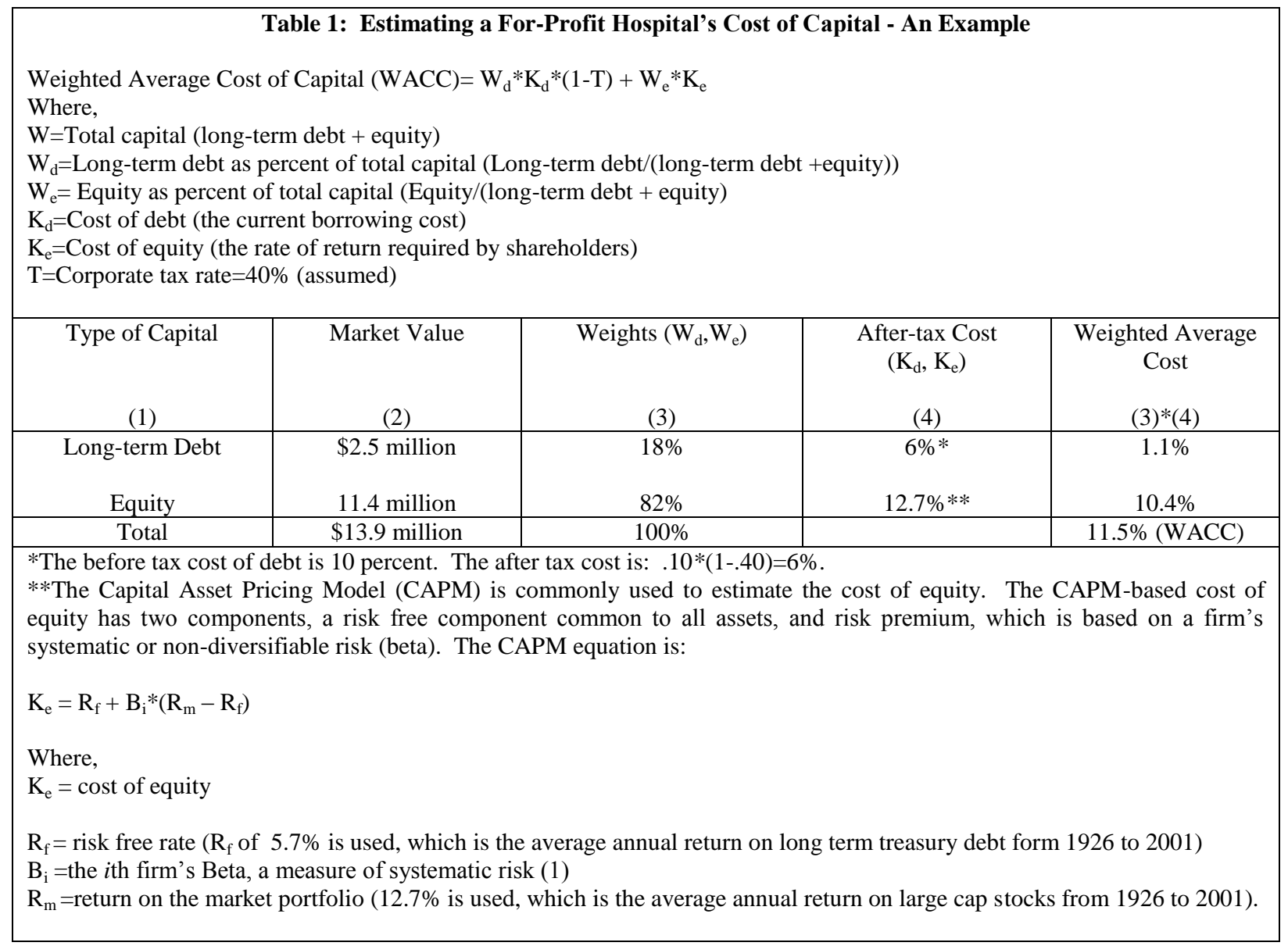

Some argue that a NFP hospital should expect zero return on net assets, since it is the hospital's objective to provide healthcare services to its clientele at operating cost. Evidence, on the other hand, suggests that NFP hospitals tend to use the cost of debt as their overall cost of capital. These hospitals focus on a target bond rating and their level of borrowing and new investment is based on whether or not their desired rating will be maintained (Wheeler, Smith, Rivenson, and Reiter, 2000). In general, as Table 2 shows, the above approaches result in low estimates for the cost of capital, overuse of debt, overinvestment, and eventual financial distress.

\begin{tabular}{|c|c|c|c|c|c|}
\hline Assumption & $\begin{array}{l}\text { Type of } \\
\text { Capital } \\
\text { (1) }\end{array}$ & $\begin{array}{c}\text { Value } \\
\text { (2) }\end{array}$ & $\begin{array}{c}\text { Weights (Wd, We) } \\
\text { (3) }\end{array}$ & $\begin{array}{c}\text { Cost } \\
(\mathrm{Kd}, \mathrm{Ke}) \\
(4)\end{array}$ & $\begin{array}{c}\text { Weighted } \\
\text { Average Cost } \\
(3)^{*}(4)\end{array}$ \\
\hline $\begin{array}{l}\text { 1. Cost of net } \\
\text { assets }=0\end{array}$ & $\begin{array}{l}\text { Long-term } \\
\text { Debt } \\
\text { Net assets }\end{array}$ & $\begin{array}{l}\$ 2 \text { million } \\
8 \text { million }\end{array}$ & $80 \%$ & $\begin{array}{l}6 \% \\
0 \%\end{array}$ & $1.2 \%$ \\
\hline Total & & $\$ 10$ million & $100 \%$ & & (WACC) \\
\hline $\begin{array}{l}\text { 2. Cost of net } \\
\text { assets }=\text { cost of } \\
\text { debt }=\text { cost of } \\
\text { capital }\end{array}$ & $\begin{array}{c}\text { Long-term } \\
\text { Debt }\end{array}$ & $\begin{array}{l}\$ 2 \text { million } \\
8 \text { million }\end{array}$ & $20 \%$ & $6 \%$ & $1.2 \%$ \\
\hline Total & & \$10 million & $100 \%$ & & $6 \%$ (WACC) \\
\hline
\end{tabular}


Already there is some evidence that hospitals may be over investing. Medicare Cost Reports from 19982002 suggest that the total assets in the hospital industry grew at an average annual rate of 4 percent, outpacing the annual inflation rate. However, hospitals have become more leveraged: the debt to total assets ratio was 47.5 percent in 1998, compared to 48.9 percent in 2002 (Cleverly and Cleverly, 2005).

Knowledge of their cost of capital will enable NFP hospitals to make the most desirable investments that will exceed or at least equal their cost of capital. These investments will not only provide the desired amount of charity care but will also enable these hospitals to compete more effectively with for-profit hospitals. The following methodology is recommended for calculating a NFP hospital's cost of capital.

First, a NFP hospital must determine the level of charity care that is consistent with the organizational mission. This level needs to be expressed quantitatively, say, as a percent of net revenue, as stipulated by some states as a requirement for NFP hospitals to maintain their tax-exempt status. Assume our hospital is employing a desired mix of debt (20 percent) and net assets ( 80 percent). Then, of the two components, the cost of debt is fairly easy to estimate. It is simply the rate that lenders charge the hospital for borrowing today (assumed to be 6 percent in our example).

Estimating the cost of net assets, however, is challenging since its equity (net assets) is not publicly traded. In the absence of freely available information, a similar, publicly traded firm is often employed as a proxy for the private firm in empirical research. Following this approach and using the Capital Asset Pricing Model (CAPM), the for-profit hospital's beta can be used as a proxy for the non-profit's beta. The Compustat database (now Research Insight) lists eight publicly traded hospitals (SIC 806), with a median levered beta of 1 and the associated debtequity ratio of 22 percent. This beta should be unlevered and then adjusted for the non-profit's financial leverage (Hamada, 1972). Using the above values and solving the following equation for $B_{u}$ gives us a value of 0.88 for the unlevered beta

$\mathrm{B}_{\mathrm{L}}=[1+(1-\mathrm{T}) \mathrm{D} / \mathrm{E}] \mathrm{B}_{\mathrm{u}}$

Where,

$\mathrm{B}_{\mathrm{L}}=$ Levered beta ( 1 in our example)

$\mathrm{T}=$ Tax rate $(40$ percent)

$\mathrm{B}_{\mathrm{u}}=$ Unlevered beta

$\mathrm{D} / \mathrm{E}=$ Long-term debt to equity ratio (22 percent)

Using the above equation for a second time but now solving it for $\mathrm{B}_{\mathrm{L}}$, our hospital's levered beta, yields a value of 1.1 (Note: the D/E ratio is 25 percent and the tax rate is zero for our tax-exempt organization). Finally, using the CAPM equation (Table 1) and the long-term estimates of 5.7 percent and 12.7 percent for $R_{f}$ and $R_{m}$, respectively, gives us a cost of 13.4 percent (see Table 3 below).

Since our NFP must provide charity care, an adjustment to its cost of net assets must be made. The following equation yields the amount of capital required to produce the desirable level of charity care. This capital will be employed with the expectation of zero return:

$\mathrm{NA}_{0}=\mathrm{X} * \mathrm{R}_{1} / \mathrm{AT}$,

Where,

$\mathrm{NA}_{0}=\mathrm{Net}$ assets to be deployed at zero cost

$\mathrm{AT}=$ Net patient revenue/total assets

$X=$ Percent of net patient revenue that will produce the desired level of charity care.

$\mathrm{R}_{1}=$ Next year's expected net patient revenue 
In our example we assume values of 0.8 for $\mathrm{AT}$, 4 percent for $\mathrm{X}$, and $\$ 8.4$ million for $\mathrm{R}_{1}$. Using the above equation, we obtain a value of $\$ 420,000$ for net assets that will be devoted to charity care with zero expected return. All of the calculations are displayed in Table 3. Our NFP hospital's cost of capital is 11.4 percent.

The above methodology is presented as a general approach to calculating a NFP organization's cost of capital. It is amenable to refinements to serve an organization's specific needs.

\begin{tabular}{|c|c|c|c|c|}
\hline $\begin{array}{c}\text { Type of Capital } \\
\text { (1) }\end{array}$ & $\begin{array}{l}\text { Value } \\
\text { (2) }\end{array}$ & $\begin{array}{l}\text { Value Weights (Wd, } \\
\text { We) } \\
\text { (3) }\end{array}$ & $\begin{array}{c}\text { Cost } \\
(\mathrm{Kd}, \mathrm{Ke}) \\
(4)\end{array}$ & $\begin{array}{c}\text { Weighted Average } \\
\text { Cost } \\
(3) *(4) \\
\end{array}$ \\
\hline Long-term Debt & \$2million & $20 \%$ & $6 \%$ & $1.2 \%$ \\
\hline $\begin{array}{l}\text { Net assets at risk- } \\
\text { adjusted cost }\end{array}$ & 7.58 million & $75.8 \%$ & $13.4 \%$ & $10.16 \%$ \\
\hline Net assets at zero cost & 0.42 million & $4.2 \%$ & $0 \%$ & $0 \%$ \\
\hline Total & $\$ 10$ million & $100 \%$ & & $11.4 \%$ (WACC) \\
\hline
\end{tabular}

\section{APPLICATIONS AND IMPLICATIONS}

Textbooks at present do not prescribe a methodology to estimate a NFP's cost of capital and not-for-profit hospitals do not appear to account for the full cost of their capital. NFPs must abide by the law and provide the level of charitable care as required or risk losing their non-profit status. As Bribiesca (2007) proffers, risk is inherent in business decisions. Since risks are inherent in an NFP's efforts, the true level or cost of the risk must be understood. As mentioned earlier, potential insolvency is a real threat on the horizons of many in health care.

Since NFP capital comes in the form of grants and donations that appear to have no direct cost attached to them, NFP hospitals tend to over-invest without regard to the true cost of doing business in a competitive environment. Managers of NFP hospitals need to use the same strategy as their for-profit counterparts and appraise their true cost of capital adjusted for charity. This will help the NFP accomplish its mission in a competitive business environment. By assuring a fair return based on a fair appraisal of true costs, hospitals can maintain competitiveness and provide services that the law requires.

\section{CONCLUSION}

Not-for-profit hospitals need to tell their story as accurately as possible to fend off any concerns or criticisms that may arise from those outside of the health care arena and to assure their success. Their true costs of operations must be recognized and accounted for in financial reporting. Historically, many have failed to recognize their true cost of capital. Only by recognizing and accounting for the true cost of capital is a firm prepared for the future. Failure to account for the true cost of capital reduces the ability of not-for-profits to serve their market area. Indeed, it imperils their very existence.

\section{AUTHOR INFORMATION}

Dr. Rakesh Duggal is a Professor of Finance at Southeastern Louisiana University. His research interests include corporate governance, mergers and acquisitions, and healthcare financial management.

Dr. Michael Craig Budden is Mayfield Professor of Marketing at Southeastern. His research interests include intellectual property protection, ethics, marketing strategy and health care marketing. 


\section{REFERENCES}

1. Brealey, R., Meyers, S., and Allen, F. (2006). Principles of Corporate Finance, $8^{\text {th }}$ edition, McGraw-Hill Irwin.

2. Bribiesca Aguirre, Juan Carlos, (2007, July). Risk management: Impact of the macroeconomic variables in the stock market sectors. International Business and Economics Research Journal, Vol. 6, No. 7: 59-66.

3. Cleverly, W. \& Cleverly, J. (2005, January/February). Overview of investment and financing trends in the hospital industry. Journal of Healthcare Management, 12-15.

4. Hamada, R. S. (1972, May). The effect of the firm's capital structure on the systematic risk of common stocks. Journal of Finance, 435-452.

5. Holstein, A. and Litzinger, P. (2008, October). Health care financing and design: Convergent trends in North America and Europe. International Business and Economics Research Journal, Vol. 7, No. 10: 1520.

6. Wheeler, J., Smith, D., Rivenson, H., \& Reiter, K. (2000, summer). Capital structure strategy in health care systems. Journal of Health Care Finance, 42-53. 


\section{NOTES}

